\title{
Carcass characteristics of South African native chicken lines
}

\author{
E. Van Marle-Köster ${ }^{\#}$ and E.C. Webb \\ Department of Animal and Wildlife Sciences, University of Pretoria, Pretoria 0002, South Africa
}

\begin{abstract}
Carcass characteristics of the Koekoek, New Hampshire, Naked-Neck, Lebowa-Venda and Ovambo chicken lines were evaluated. The highest dressed-carcass mass was recorded for Ovambo chickens and the highest percentage breast muscle was recorded for Naked-Neck chickens. Percentage fat and fatty acid composition differed between lines $(p<0.05)$. Carcass mass and fat content of the native chicken lines were less than in a commercial broiler line. It was concluded that the Ovambo and New Hampshire chicken lines appear to have the most suitable carcass characteristics for low-input systems where poultry production is aimed at household food security
\end{abstract}

Keywords: chicken, carcass composition, fatty acids

\#Author to whom correspondence should be addressed. E-mail: ekoster@postino.up.ac.za

\section{Introduction}

Households throughout the developing world keep native chickens. It is estimated that these chickens contribute up to $50 \%$ of the eggs produced in South Asian countries (Banarjee \& Sharma, 1998). Many rural South African households also keep chickens, but limited data is available on their contribution to food security. The aim of this experiment was to quantify carcass characteristics of the Koekoek, New Hampshire, Ovambo, LebowaVenda and Naked-Neck chicken lines.

\section{Materials and methods}

Day-old chickens were obtained from the ARC Animal Improvement Institute, Irene, South Africa, and raised in an environmentally controlled house over a period of 77 days. The experimental animals consisted of 160 Koekoek, 160 New Hampshire, 113 Naked-Neck, 120 Lebowa-Venda and 105 Ovambo chickens. Although the New Hampshire is not indigenous to South Africa, it was included in the experiment because it is commonly kept under conditions similar to those prevailing in systems in which Native chicken lines are kept, i.e. free-range and semi-extensive conditions. The Cobb, a commercial broiler line, was included for comparative purposes. Birds were reared on a commercial broiler starter diet from 1-14 days of age and subsequently fed a broiler finisher diet until 77 days of age. Males and females were not separated.

At the end of the growth period, ten birds were randomly selected, weighed and slaughtered. Chickens were electrically stunned and killed by manual exsanguination. Feathers, viscera and heads were removed and carcasses stored at $-40^{\circ} \mathrm{C}$ until dissected. Carcasses were thawed before dissection and the feet and abdominal fat were removed. The masses of the M. pectoralis and M. supracoracoid, as well as the masses of the appendicular and axial skeleton were recorded. The dissected carcasses, which included the muscle, bone, fat, skin and feet were ground with a mincer to obtain a homogenous sample for fatty acid analysis (Webb et al., 1994). Lipids were extracted by a modification of the chloroform-methanol (2:1 v/v) method (AOAC, 1975). Methyl esters of the fatty acid component of neutral triglycerides were prepared according to the $\mathrm{NaOH}$-methanol method (Slover \& Lanza, 1979). Dry matter, organic matter and crude protein concentrations of minced carcass samples were analyzed using AOAC (1990) procedures.

Statistical analysis was done using the GLM procedure of Statistical Analysis Systems (1985).

\section{Results and discussion}

The dressed carcass mass of the Cobb broiler line was higher $(p<0.05)$ than that of the native lines (Table 1). Among the native lines, the highest dressed carcass mass was recorded for the Ovambo (939.8 g). The carcass muscle content for most native lines was in the region of 55\%, with the exception of the Ovambo and New Hampshire lines in which muscle constituted only $51 \%$ of the carcass. The Naked-Neck chickens had the highest breast muscle content $(18.03 \% \pm 0.5 \%)$ of the native lines. 
Table 1 Least square means for dressed carcass mass (g) and carcass content of muscle, breast muscle, fat, skin and bone in various lines of native chickens. Standard errors of the means are indicated in parentheses.

\begin{tabular}{|c|c|c|c|c|c|c|}
\hline Line & $\begin{array}{l}\text { Dressed } \\
\text { carcass } \\
\text { mass* } \\
(\mathrm{g}) \\
\end{array}$ & $\begin{array}{c}\text { Muscle } \\
(\%)\end{array}$ & $\begin{array}{c}\text { Breast muscle } \\
(\%)\end{array}$ & $\begin{array}{l}\text { Fat } \\
(\%)\end{array}$ & $\begin{array}{l}\text { Skin } \\
(\%)\end{array}$ & $\begin{array}{l}\text { Bone } \\
(\%)\end{array}$ \\
\hline Koekoek & $\begin{array}{c}831.6^{\mathrm{abc}} \\
(35.9)\end{array}$ & $\begin{array}{l}54.9^{\mathrm{ac}} \\
(0.8)\end{array}$ & $\begin{array}{l}17.0^{\mathrm{ac}} \\
(0.5)\end{array}$ & $\begin{array}{l}1.2^{\mathrm{ac}} \\
(0.5)\end{array}$ & $\begin{array}{l}10.6^{\mathrm{a}} \\
(0.5)\end{array}$ & $\begin{array}{l}33.2^{\mathrm{a}} \\
(0.9)\end{array}$ \\
\hline New Hampshire & $\begin{array}{c}907.0^{\text {be }} \\
(35.9)\end{array}$ & $\begin{array}{l}51.7^{\mathrm{ab}} \\
(0.8)\end{array}$ & $\begin{array}{c}15.9^{\mathrm{ab}} \\
(0.5)\end{array}$ & $\begin{array}{l}4.34^{\mathrm{b}} \\
(0.5)\end{array}$ & $\begin{array}{l}12.8^{\mathrm{b}} \\
(0.5)\end{array}$ & $\begin{array}{l}31.1^{\mathrm{a}} \\
(0.9)\end{array}$ \\
\hline Naked-Neck & $\begin{array}{c}795.6^{\mathrm{cd}} \\
(35.9)\end{array}$ & $\begin{array}{l}54.9^{c} \\
(0.8)\end{array}$ & $\begin{array}{l}18.0^{\mathrm{c}} \\
(0.5)\end{array}$ & $\begin{array}{l}1.8^{\mathrm{a}} \\
(0.4)\end{array}$ & $\begin{array}{c}11.7^{\mathrm{ab}} \\
(0.5)\end{array}$ & $\begin{array}{l}31.5^{\mathrm{a}} \\
(0.9)\end{array}$ \\
\hline Lebowa-Venda & $\begin{array}{l}703.9^{\mathrm{d}} \\
(35.9)\end{array}$ & $\begin{array}{l}53.0^{\mathrm{b}} \\
(0.8)\end{array}$ & $\begin{array}{l}15.2^{\mathrm{d}} \\
(0.5)\end{array}$ & $\begin{array}{l}0.4^{\mathrm{C}} \\
(0.4)\end{array}$ & $\begin{array}{l}10.3^{\mathrm{a}} \\
(0.5)\end{array}$ & $\begin{array}{l}36.2^{\mathrm{b}} \\
(0.9)\end{array}$ \\
\hline Ovambo & $\begin{array}{l}939.8^{\mathrm{e}} \\
(37.5)\end{array}$ & $\begin{array}{l}51 .^{9 a b} \\
(0.8)\end{array}$ & $\begin{array}{c}15.9^{\mathrm{ab}} \\
(0.5)\end{array}$ & $\begin{array}{l}2.5^{\mathrm{a}} \\
(0.4)\end{array}$ & $\begin{array}{l}12.1^{\mathrm{cb}} \\
(0.5)\end{array}$ & $\begin{array}{l}33.5^{\mathrm{a}} \\
(0.9)\end{array}$ \\
\hline Cobb & $\begin{array}{c}1404.7^{\mathrm{f}} \\
(37.5)\end{array}$ & $\begin{array}{l}55.2^{\mathrm{d}} \\
(0.8)\end{array}$ & $\begin{array}{l}20.4^{\mathrm{d}} \\
(0.8)\end{array}$ & $\begin{array}{l}6.5^{\mathrm{d}} \\
(0.4) \\
\end{array}$ & $\begin{array}{c}14.2^{\mathrm{bd}} \\
(0.5)\end{array}$ & $\begin{array}{l}24.1^{\mathrm{c}} \\
(0.9)\end{array}$ \\
\hline
\end{tabular}

*Head and viscera removed. Variables in the same column with different superscripts differ significantly $(p<0.05)$.

Table 2 Least square means for dry matter, ash, crude protein and crude fat content of the carcasses of various chicken lines. Standard errors of the means are indicated in parentheses.

\begin{tabular}{lcccc}
\hline \multicolumn{1}{c}{ Line } & $\begin{array}{c}\text { Dry matter } \\
\%\end{array}$ & $\begin{array}{c}\text { Ash } \\
\%\end{array}$ & $\begin{array}{c}\text { Crude protein } \\
\%\end{array}$ & $\begin{array}{c}\text { Crude fat } \\
\%\end{array}$ \\
\hline Koekoek & $35.4^{\mathrm{ab}}(2.2)$ & $3.9^{\mathrm{ab}}(0.4)$ & $46.1^{\mathrm{a}}(1.2)$ & $28.5^{\mathrm{a}}(1.6)$ \\
New Hampshire & $35.9^{\mathrm{ab}}(1.9)$ & $3.78^{\mathrm{a}}(0.3)$ & $42.2^{\mathrm{bc}}(1.2)$ & $36.9^{\mathrm{bc}}(1.6)$ \\
Naked-Neck & $35.9^{\mathrm{ab}}(2.0)$ & $3.9^{\mathrm{ab}}(0.3)$ & $45.2^{\mathrm{ab}}(1.2)$ & $34.9^{\mathrm{b}}(1.6)$ \\
Lebowa-Venda & $31.4^{\mathrm{a}}(1.9)$ & $4.7^{\mathrm{b}}(0.3)$ & $49.6^{\mathrm{d}}(1.1)$ & $28.8^{\mathrm{a}}(1.6)$ \\
Ovambo & $38.5^{\mathrm{b}}(2.2)$ & $2.7^{\mathrm{c}}(0.4)$ & $44.8^{\mathrm{ab}}(1.5)$ & $36.0^{\mathrm{bc}}(2.1)$ \\
Cobb & $34.4^{\mathrm{ab}}(1.7)$ & $2.4^{\mathrm{c}}(0.3)$ & $39.9^{\mathrm{c}}(1.1)$ & $40.6^{\mathrm{c}}(1.5)$ \\
\hline
\end{tabular}

Variables in the same column with different superscripts differ significantly $(p<0.05)$.

Data on the carcass characteristics of native chickens are scarce. Safalaoh et al. (1996) reported a carcass breast muscle content of $14.81 \%$ for the Malawi chicken, which is similar to that recorded in this study. Chambers et al. (1981) compared the modern broiler type chicken with birds representative of the broiler lines prevalent in 1958 and 1972. The carcass breast muscle content reported by Safalaoh et al. (1996) was lower than that reported by Chambers et al. (1981) for broilers representative of 1958-type lines (25.2\%) and 1972-type lines (23.9\%). In the study of Chambers et al. (1981), the dressed carcass mass for males at 47 days of age was $717 \mathrm{~g}$ for the 1958type line, $967 \mathrm{~g}$ for the 1972-type line and $1088 \mathrm{~g}$ for the modern broiler type. The masses recorded for the native lines in the present study are comparable with the masses of the 1958 and 1972 broiler lines. Leeson \& Summers (1980) reported a breast muscle content of $31.3 \%$ for modern broilers slaughtered at 35 days of age. Wall \& Anthony (1995) found that there were no differences between the total breast mass (bone included) of the Giant Jungle Fowl and broilers, but reported that the Jungle Fowl had less breast muscle when de-boned. 
Carcasses of the native lines contained less $(p<0.05)$ fat than those of the control line (Table 1$)$. The Lebowa-Venda line had the lowest fat content $(0.42 \%)$ and the Ovambo had the highest fat content $(2.5 \%)$. The fastest growth rates among native lines were recorded for the Ovambo and New Hampshire lines. These lines also reached sexual maturity (age at first egg) six weeks before the Koekoek, Naked-Neck and Lebowa-Venda. The higher fat contents and faster growth rates of the Ovambo and New Hampshire lines indicate that these are early maturing types. The Lebowa-Venda line had the slowest growth rate, reached sexual maturity last and also had the lowest carcass fat percentage and crude fat content. The native lines had a higher bone content than the control line. The higher bone content may be associated with adaptation to flight and scavenging. The lowest crude protein content was recorded for the Cobb and the highest for the Lebowa-Venda (Table 2). Crude fat content was highest in the Cobb and the lowest in the Lebowa-Venda and Koekoek lines.

Table 3 Carcass fatty acid composition (molar \%) of various chicken lines.

\begin{tabular}{llllllll}
\hline \multicolumn{1}{c}{ Line } & \multicolumn{7}{c}{ Fatty acid } \\
\cline { 2 - 7 } & $14: 0$ & $16: 0$ & $16: 1$ & $18: 0$ & $18: 1$ & $18: 3$ & $20: 1$ \\
\hline Koekoek & 1.05 & $24.58^{\mathrm{abc}}$ & $7.92^{\mathrm{a}}$ & 8.23 & $45.28^{\mathrm{ab}}$ & $12.18^{\mathrm{bc}}$ & 1.54 \\
New Hampshire & 0.85 & $25.83^{\mathrm{bc}}$ & $9.85^{\mathrm{c}}$ & 7.74 & $44.27^{\mathrm{ab}}$ & $10.12^{\mathrm{ab}}$ & 1.92 \\
Naked-Neck & 1.15 & $25.10^{\mathrm{bc}}$ & $8.19^{\mathrm{ab}}$ & 7.82 & $42.74^{\mathrm{a}}$ & $12.87^{\mathrm{c}}$ & 2.34 \\
Lebowa-Venda & 1.29 & $22.17^{\mathrm{a}}$ & $7.98^{\mathrm{a}}$ & 6.99 & $45.06^{\mathrm{ab}}$ & $14.44^{\mathrm{c}}$ & 2.05 \\
Ovambo & 0.92 & $23.71^{\mathrm{ab}}$ & $9.23^{\mathrm{bc}}$ & 6.07 & $46.68^{\mathrm{b}}$ & $12.72^{\mathrm{c}}$ & 1.33 \\
Cobb & 0.92 & $26.62^{\mathrm{c}}$ & $8.78^{\mathrm{abc}}$ & 8.37 & $43.11^{\mathrm{a}}$ & $9.58^{\mathrm{a}}$ & 2.42 \\
\hline
\end{tabular}

Variables in the same column with different superscripts differ significantly $(p<0.05)$.

The highest proportions of 16:1 fatty acid were observed in the Ovambo, New Hampshire and Naked-Neck lines (Table 3). The proportions of linoleic and linolenic acid were highest in the Ovambo, Koekoek and LebowaVenda lines. Diet and dietary fat content may influence the proportions of these fatty acids (Hrdinka et al., 1996). Since the chickens in the present study received the same diets, the differences in the proportions of unsaturated fatty acids were probably due to differences in eating behavior. The Ovambo, New Hampshire and Naked-Neck lines tend to scratch while eating and were observed to pick up food particles more selectively than broilers. Although no differences were observed between lines for stearic acid (18:0) and arachidic acid (20:0) content, the proportion of palmitic acid (16:0) differed $(p<0.05)$ between lines. Breed-related differences in fatty acid composition have previously been reported for sheep (Webb \& Casey, 1995). The differences observed between native chicken lines could also be genetically based, but further study is required to confirm this.

The native lines had low carcass yields due to their slower growth, and had higher bone and lower fat contents than the commercial broilers. Native lines have not been selected for growth or carcass traits. The data indicate that the Ovambo and New Hampshire lines tend to be early maturing in terms of growth and carcass traits, while the Lebowa-Venda is a late maturing type. The Koekoek and Naked-Neck lines are intermediate.

\section{Conclusions}

The Ovambo and New Hampshire chicken lines appear to be the most suitable lines in terms of carcass characteristics, for low-input systems where poultry production is aimed at household food security. Further research is required to evaluate growth characteristics under semi-intensive conditions and to determine sensory characteristics and consumer acceptability of meat from native chicken lines.

\section{References}

AOAC, 1975. Official methods of analysis. Association of official analytical chemists. Washington, D.C. AOAC, 1990. Official methods of analysis. Association of official analytical chemists. Washington, D.C.

Banarjee, A.K. \& Sharma, R.K., 1998. Breeding possibilities in adverse climatic conditions with special reference to Indian conditions. Proc. $10^{\text {th }}$ European poultry conference. Jerusalem, Israel.

Chambers, J.R., Gavora, J.S. \& Fortina, A., 1981. Genetic changes in meat-type chickens in the last twenty years. Can. J. Anim. Sci. 61, 555-563. 
Hrdinka, C., Zollitsch, W., Knaus, W. \& Lettner, F., 1996. Effects of dietary fatty acid pattern on melting point and composition of adipose tissues and intramuscular fat of broiler carcasses. Poultry Sci. 75, 208-215.

Leeson, S. \& Summers, J.D., 1980. Production and carcass characteristics of the broiler chicken. Poultry Sci. 59, 768-798.

Safalaoh, A.C.L., Kadigi, H.J.S. \& Phoya, R.K., 1996. Growth performance and carcass characteristics of male Black Australorp, Dwarf Malawi local chicken and their crosses from 8-20 weeks of age. Uniswa. Res. J. Agric. Sci \& Tech. 1, 61-67.

Slover, H.T. \& Lanza, E., 1979. Quantitative analysis of food fatty acids by capillary gas chromatography. J. Am. Oil Chem. Soc. 56, 933.

Statistical Analysis Systems, 1985. SAS User's Guide: Statistics, version 5. SAS Institute Inc., Cary, NC.

Wall, C.W. \& Anthony, N.B., 1995. Inheritance of carcass variables when Giant Jungle Fowl and broilers achieve a common physiological body mass. Poultry Sci. 74, 231-236.

Webb, E.C., Casey, N.H. \& Van Niekerk, W.A., 1994. Fatty acids in the subcutaneous adipose tissue of intensively fed SA Mutton Merino and Dorper wethers. Meat Sci. 38, 123-131.

Webb, E.C. \& Casey, N.H., 1995. Genetic differences in fatty acid composition of subcutaneous adipose tissue in Dorper and SA Mutton Merino wethers at different liveweights. Small Rum. Res. 18, 81-88. 